\title{
Tihkukastelun ja kastelulannoituksen vaikutus mansikanviljelyn talouteen
}

\author{
Pia Outa ja Kalle Kankaanhuhta \\ MTT Taloustutkimus, Luutnantintie 13, 00410 Helsinki, \\ pia.outa@mtt.fijakalle.kankaanhuhta@mtt.fi
}

\begin{abstract}
Johdanto
Kastelun hallinta on oleellinen osa puutarhakasvien laatutuotantoa, jossa pyritään riittävän suureen ja laadukkaaseen satoon ja hyvään taloudelliseen tulokseen. Tihkukastelua käytetään ja sitä on tutkittu erityisesti Välimeren maissa ja Yhdysvalloissa. Hyödyt ovat todennäköisiä myös Suomen ilmastossa, sillä tihkukastelulla voidaan puutarhakasveilla päästä lähes samoihin satotasoihin kuin KeskiEuroopassa. Tihkukastelu mahdollistaa myös erikoiskasvinviljelyn paikoilla, missä vesi ei riittäisi normaaliin pintakasteluun. Kuitenkin uusien menetelmien, kuten tihkukastelun, käyttöönotto on synnyttänyt kysymyksiä mm. menetelmän taloudellisesta kannattavuudesta.
\end{abstract}

\section{Tavoite}

Tihkukastelun taloustutkimus on osa vuosina 2001 - 2003 käynnissä ollutta MTT:n ja Työtehoseuran tutkimusta 'Tihkukastelu ja kastelulannoitus puutarhakasvien sadon varmistajana avomaalla'. MTT taloustutkimuksessa selvitettiin tihkukastelun taloudellisuus avomaan puutarhakasveilla tavanomaiseen tuotantotapaan verrattuna. Tutkimuksessa selvitettiin tihkukastelusta ja tavanomaisesta kastelujärjestelmästä aiheutuvia tuottoja ja kustannuksia ja edelleen niiden taloudellisen tuloksen muodostumista.

\section{Aineisto ja menetelmät}

Tutkimuksessa oli mukana puutarhatiloja, jotka olivat viime vuosina perustaneet puutarhakasvustoja tihkukastelujärjestelmällä. Tutkittavina kasveina olivat yksivuotinen avomaankurkku sekä monivuotiset mansikka ja mustaherukka. Tutkimukseen osallistuvilta tiloilta kerättiin kastelujärjestelmän perustamista koskevat työnkäyttötiedot, tihkukastelun investointikustannukset sekä vuotuiset työnmenekkija kassamenotiedot. Tietoja kerättiin vuosilta 2001 - 2003.

Talouslaskelmat tehtiin tilamallitarkasteluna. Tilamalleilla voidaan tarkastella tihkukastelujärjestelmän taloudellista vaikutusta viljelyyn muiden viljelyoletusten pysyessä ennallaan. Tiloilta kerättyjen tietojen perusteella laadittiin tihkukastelua kuvaavat tilamallit jokaiselle tutkittavalle puutarhakasville. Mansikasta ja mustaherukasta oli jo olemassa perinteistä viljelytapaa kuvaavat mallilaskelmat, joihin uusia tihkukastelumalleja verrattiin.

Jokaiselle kasville on laadittu kaksi eri kokoista tilamallia. Pienempi tilamalli A kuvaa käsityövaltaista perheviljelmää, suurempi malli B kuvaa koneistettua, palkkatyövoimavaltaista tuotantotapaa. Malleilla lasketaan tuotantokustannukset sekä viljelyn tuotot ja kannattavuus.

\section{Tulokset ja tulosten tarkastelu}

Tässä esitetään mansikantuotantoa koskevat tulokset. Tarkasteltavia mallilaskelmia on neljä, tihkukastelua kuvaavat mallit A ja B (tihkumansikka) sekä perinteistä tuotantotapaa kuvaavat mallit A ja B (perinteinen mansikka). Tilamalleissa A on satoikäistä mansikkaa 3 hehtaaria ja tilamallissa B 8 hehtaaria. Koko mansikan viljelyala on mallissa A 3,75 ha ja mallissa B 10 ha. Perinteisen mansikan satotaso on $5000 \mathrm{~kg} / \mathrm{ha}$ ja tihkumansikan $10000 \mathrm{~kg} / \mathrm{ha}$. Koko sato myydään palkkapoimittuna tukkuun 5 $\mathrm{kg}: \mathrm{n}$ laatikoissa.

Tihkukastelumenetelmällä tuotetun mansikan tuotantokustannus oli $2,27 € / \mathrm{kg}$ tilamallissa $\mathrm{A}$ ja $2,11 € /$ kg tilamallissa B (taulukko 1). Tuotantokustannukset hehtaaria kohden laskettuna olivat vastaavasti 22680 ja 21148 euroa.

Karkeasti jaoteltuna viljelytarvikkeet ja omaisuudesta aiheutuvat kustannukset muodostavat molemmat viidenneksen mansikan tuotantokustannuksista. Mansikanviljelyn suurin kustannuserä on työkustannus, joka muodostaa noin $60 \%$ tuotantokustannuksesta. Suurin osa työpanoksesta, $80 \%$, sitoutuu mansikan poimintaan. Tihkukastelulla saavutettava korkeampi satotaso lisää poimintatyön menekkiä samassa suhteessa, sillä poimintanopeus on oletettu vakioksi (10 kg tunnissa). Tihkumansikan työmenekki on hieman perinteistä tuotantotapaa suurempi. Kasvuston perustamisessa ja raivauksessa työmenekki on yhteensä 16 tuntia suurempi ja vuotuisen viljelytyön menekki kuusi tuntia suurempi hehtaaria kohden. 
Taulukko 1. Mansikan tuotantokustannus (€/kg) tihkukastelulla ja perinteisellä viljelymenetelmällä.

\begin{tabular}{|lcccc|}
\hline \multicolumn{1}{|c}{ eur/kg } & \multicolumn{2}{c|}{ Mansikkamalli A } & \multicolumn{2}{c|}{ Mansikkamalli B } \\
& tihku & perinteinen & tihku & perinteinen \\
\hline Tuotantokustannus & & & & \\
- ilman yrittäjän palkkavaatimusta & 1,98 & 2,66 & 1,91 & 2,46 \\
- yrittäjän palkkavaatimus ml. & 2,27 & 3,22 & 2,11 & 2,88 \\
\hline
\end{tabular}

Tihkulaitteiston investointikustannus mansikkahehtaaria kohden oli 2090 euroa mallissa A ja 1193 euroa mallissa B. Laskelmassa kustannukset kohdistetaan satoikäiseen kasvustoon. Tihkumansikan suurempi pääomakanta nosti omaisuudesta aiheutuvia kustannuksia mallissa A noin 1350 euroa ja mallissa B noin 2480 euroa tilaa kohti.

Myös lannoituskustannus oli tihkumalleissa noin $300 € /$ ha korkeammat kuin perinteisen tuotannon malleissa. Tihkuletkujen kautta annettavien kastelulannoitteiden hinnat ovat korkeampia kuin rakeisten lannoitteiden.

Kun kokonaistuotoista vähennetään viljelyn muuttuvat ja kiinteät kustannukset, saadaan varsinaisen liiketoiminnan tulosta kuvaava liikevoitto/-tappio. Tuottojen laskennassa on käytetty vuoden 2002 keskihintaa, joka on $2,33 € / \mathrm{kg}$. Pinta-alatukien kanssa laskettuna kokonaistuotot olivat $2,42 € / \mathrm{kg}$. Laskelmassa käytetyillä oletuksilla molemman tihkumallit tuottivat voittoa. Parhaaseen taloudelliseen tulokseen ylsi tihkumalli $\mathrm{B}$, joka tuotti voittoa 50 snt kiloa kohden eli noin $3000 € /$ ha. Kannattavuusero perinteisiin mansikantuotannon malleihin on merkittävä, sillä molemmilla tilamalleilla perinteinen tuotanto on tappiollista.

Tihkukastelumenetelmä lisää mansikan tuotantokustannuksia hehtaaria kohden noin 6600 6700 euroa eli $41-47 \%$, kun sato-oletus on $10000 \mathrm{~kg} / \mathrm{ha}$. Tihkukastelulla on kuitenkin mahdollista nostaa satotasoa merkittävästi perinteiseen tuotantotapaan verrattuna, jolloin tuotantokustannukset kiloa kohden alenevat (noin 25 -30 \%). Vuoden 2002 tuottajahinnalla laskettuna suuremmasta sadosta saatu myyntitulojen kasvu on mallilaskelmissa suurempi kuin tihkukastelusta aiheutuvat kustannukset. Mallilaskelma on kuitenkin herkkä siinä käytettyjen oletusten suhteen. Mallit eivät myöskään ota huomion tuotannollisia riskejä esim. sadon onnistumisen ja markkinahinnan muutosten suhteen. 